\title{
Susceptibility of pike Esox lucius to a panel of Ranavirus isolates
}

\author{
Britt Bang Jensen ${ }^{1,2, *}$, Annette Kjær Ersbøll ${ }^{1}$, Ellen Ariel ${ }^{2,3}$ \\ ${ }^{1}$ Department of Large Animal Sciences, Faculty of Life Sciences, University of Copenhagen, Grønnegårdsvej 8, \\ 1870 Frederiksberg $C$, Denmark \\ ${ }^{2}$ Department of Fish, Poultry and Fur Animals, National Veterinary Institute, Technical University of Denmark, \\ Hangøvej 8, 8210 Århus N, Denmark \\ ${ }^{3}$ School of Veterinary and Biomedical Sciences, James Cook University - Douglas Campus, Townsville, \\ 4810 Queensland, Australia
}

\begin{abstract}
In order to study the pathogenicity of ranaviruses to a wild European freshwater fish species, pike Esox lucius fry were challenged with the following Ranavirus isolates: epizootic haematopoietic necrosis virus (EHNV), European sheatfish virus (ESV), European catfish virus (ECV), pike-perch iridovirus (PPIV), New Zealand eel virus (NZeelV) and frog virus 3 (FV3). The fry were infected using bath challenge at 12 and $22^{\circ} \mathrm{C}$. Significant mortalities were observed at $12^{\circ} \mathrm{C}$ for EHNV, ESV, PPIV and NZeelV. Background mortality was too high in the experiments performed at $22^{\circ} \mathrm{C}$ for any conclusions about viral pathogenicity at this temperature to be drawn. Viruses could be re-isolated from samples from all challenged groups, and their presence in infected tissue was demonstrated using immunohistochemistry. The findings suggest that pike fry are susceptible to EHNV, ESV, PPIV and NZeelV and can be a vector for ECV and FV3. Statistical analysis of the factors associated with positive virus re-isolation showed that the number of fish in the sample influenced the outcome of virus re-isolation. Moreover, the likelihood of positive virus re-isolation significantly differed among the 6 viral isolates. The temperature from where the sample was taken and the number of days after infection were not associated with the probability of a positive virus re-isolation.
\end{abstract}

KEY WORDS: Ranavirus $\cdot$ Pike $\cdot$ Epizootic haematopoietic necrosis virus $\cdot$ European sheatfish virus European catfish virus $\cdot$ Pike-perch iridovirus $\cdot$ New Zealand eel virus $\cdot$ Frog virus 3

\section{INTRODUCTION}

Ranavirus is a genus of the family Iridoviridae. Infection with Ranavirus is characterised by a systemic disease affecting the haematopoietic organs in fish, amphibians and reptiles. Although its taxonomy is still not fully resolved, the following species within the genus are recognised: epizootic haematopoietic necrosis virus (EHNV), European catfish virus (including European catfish virus [ECV] and European sheatfish virus [ESV]), Bohle iridovirus (BIV), frog virus 3 (FV3 and several other amphibian and reptile viruses) and Santee-Cooper Ranavirus, which includes doctor fish virus (DFV) and guppy virus 6 (GV6) (Chinchar et al. 2005).
It is not possible to differentiate the ranaviruses based on their antigenic properties, since they share conserved group-specific antigens (OIE 2006). However, viruses within the genus can be differentiated by the size of the virions. The commonly used method for identification is $\mathrm{PCR}$, followed by either sequencing or restriction endonuclease analysis, although difficulties in differentiating ESV and ECV still exist (Hyatt et al. 2000).

Until recently, the disease epizootic haematopoietic necrosis has only been recognized in Australia; however, similar diseases have caused gross mortalities in Europe in the last 2 decades, with subsequent isolation of ECV and ESV from the affected fish (Ahne et al. 1989, Pozet et al. 1992). This raised concern about the possibility of the introduction and spread of rana- 
viruses and associated diseases in European freshwater ecosystems.

In bath infection trials with EHNV, the virus was demonstrated to be pathogenic to 5 out of 13 fish species, including members of the families Salmonidae and Percichthyidae (Langdon et al. 1988, Langdon 1989). The pathogenicity of ESV has only been assessed in the original host and in red sea bream, to which it was not pathogenic (Nakajima \& Maeno 1998). No trials using ECV in species other than catfish have been reported so far. The ornamental fish isolates DFV and GV6 have not been used to challenge their original hosts, but have been shown to induce mortalities in salmonids (Hedrick \& McDowell 1995).

Of the amphibian ranaviruses, experiments infecting fish with BIV have been performed. The viral isolate proved to be highly pathogenic to barramundi Lates calcarifer (Moody \& Owens 1994). Infection with the same Ranavirus in 2 different taxonomic classes was demonstrated by Mao et al. (1999), who isolated a Ranavirus from stickleback Gasterostelus aculeatus, this virus being identical to one isolated from redlegged frog Rana aurora.

The primary aim of the present study was to determine the pathogenicity of 6 ranaviruses to wild freshwater piscivorous fish. A further aim was to evaluate factors affecting the outcome of virus re-isolation from samples obtained from fish that had died from viral exposure. The viral panel included isolates from both freshwater and marine fish species, as very little is known about the pathogenicity of these viruses outside of their natural hosts. Pike Esox lucius was chosen because of its wide distribution and importance in the freshwater ecosystem as a predator of both fish and amphibians. The species is native to the entire northern hemisphere and has been introduced in many southern European countries, either for sports fishing or as a regulator of smaller fish in lakes or rivers (Crossman 1996). Adult pike feed on many different fish species, and pike larvae and fry are an important food for some freshwater fish species (Mann 1996).

Pike have been reported to be susceptible to several different fish viruses such as viral haemorrhagic septicaemia virus (VHSV), pike fry rhabdovirus (PFR), Rhabdovirus carpio (SVCV), pike herpes virus (PHV) and cyprinid herpes virus (CHV) (Dick \& Choudhury 1996), and they can also be carriers of infectious pancreatic necrosis virus (IPNV) (Ahne 1978).

\section{MATERIALS AND METHODS}

Fish. A total of 1600 pike fry was obtained from a breeding facility. The brood stock was wild fish from the Danish lake Langesø in the central part of Sealand.
The pike spawned at the beginning of April, and the fry hatched on 22 April 2006. The fry were transported to the research facility on 1 May, after completion of yolk sac absorption. At the research facility, the fry were acclimated to a water temperature of $10^{\circ} \mathrm{C}$ and fed with live artemia twice daily (EG artemia cysts, INVE Technologies). At the time of challenge, the fry had an average weight of $0.03 \mathrm{~g}$.

On arrival at the research facility, a subsample of individuals was subjected to bacteriological examination on blood agar and Ordals agar (Lorenzen 1993), virological examination according to Commission Decision 2001/183/EC (Anonymous 2001), and examination for parasites under a light microscope. All results were negative.

Virus. The panel of 6 viral isolates used in the study and their origin are listed in Table 1. The isolates were propagated and titrated in epithelioma papulosum cyprini (EPC) cells at $20^{\circ} \mathrm{C}$, using Eagles minimal essential medium (EMEM) as the cell culture medium. The viruses caused cell lysis and complete destruction of the cell sheet. After propagation, the medium with the virus was harvested and used for the challenges.

As a control for the challenge protocol (positive control), VHS virus (strain VHSV 3592B, 2nd passage, Bluegill fry [BF2] cell line) was used, according to the infection model described by Meier \& Jørgensen (1980).

Bath challenge. On the day of the challenge, 100 ind. were moved to each of 16 aquaria. In 8 of these aquaria, the temperature was increased from 12 to $22^{\circ} \mathrm{C}$ during a $6 \mathrm{~h}$ period. The water and airflow were then stopped, the water volume in all aquaria was reduced from 8 to 21 , and virus (diluted with cell culture medium) was added, reaching a final titre of $1 \times$ $10^{4} \mathrm{TCID}_{50} \mathrm{ml}^{-1}$ in each aquarium. After $2 \mathrm{~h}$, water and airflow were restored, and 50 ind. from each aquarium were moved into a new aquarium with the same water temperature. Individuals of a control group were exposed to the same treatment, but $1 \mathrm{ml}$ of cell culture medium was added to the water instead of virus. In total, there were 32 aquaria; 4 aquaria for each of the 8 treatments ( 6 viral isolates plus positive and negative controls), with 2 of the 4 aquaria for each treatment having a water temperature of $12^{\circ} \mathrm{C}$ and the other 2 having a temperature of $22^{\circ} \mathrm{C}$.

Every morning, dead fish from each aquarium were recorded, sampled, pooled and frozen at $-80^{\circ} \mathrm{C}$ for subsequent virological examination. Moribund fish were sampled and fixed in $10 \%$ phosphate-buffered formalin for histological examination. Temperature in the aquaria was kept constant at $12 \pm 2^{\circ} \mathrm{C}$ and $22.5 \pm$ $2^{\circ} \mathrm{C}$, and logged using thermologgers (Testostor 175-1, Testo). The period of observation was $28 \mathrm{~d}$, after which 
Table 1. Ranavirus isolates used in this study. VHSV was additionally used as a positive control for the infection protocol

\begin{tabular}{|c|c|c|c|c|c|}
\hline Virus & Abbreviation & Isolated in & Host & Source & Isolate obtained from \\
\hline $\begin{array}{l}\text { Epizootic } \\
\text { haematopoietic } \\
\text { necrosis virus }\end{array}$ & EHNV & Australia & $\begin{array}{l}\text { Red-fin perch } \\
\text { Perca fluviatilis }\end{array}$ & $\begin{array}{l}\text { Langdon } \\
\text { et al. (1986) }\end{array}$ & R. Whittington, University of Sydney \\
\hline $\begin{array}{l}\text { European sheatfish } \\
\text { virus }\end{array}$ & ESV & Germany & $\begin{array}{l}\text { European sheatfish } \\
\text { Silurus glanis }\end{array}$ & $\begin{array}{l}\text { Ahne } \\
\text { et al. (1989) }\end{array}$ & W. Ahne, University of Munich \\
\hline $\begin{array}{l}\text { European catfish } \\
\text { virus }\end{array}$ & ECV & France & $\begin{array}{l}\text { European catfish } \\
\text { Ictalurus melas }\end{array}$ & $\begin{array}{l}\text { Pozet } \\
\text { et al. (1992) }\end{array}$ & $\begin{array}{l}\text { G. Bovo, Instituto Zooprofilattico } \\
\text { delle Venezie }\end{array}$ \\
\hline $\begin{array}{l}\text { Pike-perch } \\
\text { iridovirus }\end{array}$ & PPIV & Finland & $\begin{array}{c}\text { Pike-perch } \\
\text { Stizostedion lucioperca }\end{array}$ & $\begin{array}{l}\text { Tapiovaara } \\
\text { et al. (1998) }\end{array}$ & $\begin{array}{l}\text { H. Tapiovaara, National Food and } \\
\text { Veterinary Research Institute of Finland }\end{array}$ \\
\hline $\begin{array}{l}\text { New Zealand } \\
\text { eel virus }\end{array}$ & NZeelV & Italy & $\begin{array}{l}\text { Short-finned eel } \\
\text { Anguilla australis }\end{array}$ & $\begin{array}{c}\text { Bovo } \\
\text { et al. (1999) }\end{array}$ & $\begin{array}{l}\text { G. Bovo, Instituto Zooprofilattico } \\
\text { delle Venezie }\end{array}$ \\
\hline Frog virus 3 & FV3 & $\begin{array}{l}\text { North } \\
\text { America }\end{array}$ & $\begin{array}{l}\text { Leopard frog } \\
\text { Rana pipiens }\end{array}$ & $\begin{array}{l}\text { Granoff } \\
\text { et al. (1966) }\end{array}$ & W. Ahne, University of Munich \\
\hline $\begin{array}{l}\text { Viral haemorrhagic } \\
\text { septicaemia virus }\end{array}$ & VHSV & Denmark & $\begin{array}{c}\text { Rainbow trout } \\
\text { Oncorhynchus mykiss }\end{array}$ & $\begin{array}{l}\text { Lorenzen } \\
\text { et al. (1993) }\end{array}$ & $\begin{array}{l}\text { N. Lorenzen, National Veterinary } \\
\text { Institute, Technical University of } \\
\text { Denmark }\end{array}$ \\
\hline
\end{tabular}

all surviving fish were euthanized and sampled for both virological and histological examination.

Virus re-isolation. All pooled fish were subjected to virus re-isolation, according to Commission Decision 2001/183/EC (Anonymous 2001), as described below. All samples were thawed at room temperature and immediately homogenized using a mortar, pestle and sterile sand. The samples were diluted with $2 \mathrm{ml}$ sterile EMEM with $10 \%$ newborn calf serum, TRIS-buffer and penicillin $\left(100 \mathrm{U} \mathrm{ml}^{-1}\right) /$ streptomycin $\left(100 \mu \mathrm{g} \mathrm{ml}^{-1}\right)$ and centrifuged at $4000 \times g$ at $5^{\circ} \mathrm{C}$ for $20 \mathrm{~min}$. For each sample, $25 \mu \mathrm{l}$ Hexamycin $\mathrm{ml}^{-1}$ was added to the supernatant and the samples incubated at $5^{\circ} \mathrm{C}$ overnight or at $15^{\circ} \mathrm{C}$ for $4 \mathrm{~h}$. The samples were then inoculated into cultures of 24-h-old EPC cells in 24-well trays, at final dilutions of $1: 100,1: 1000$ and 1:10 000. The inoculated cell cultures were incubated at $20^{\circ} \mathrm{C}$ for $1 \mathrm{wk}$, with regular examination for cytopathic effect (CPE). After $1 \mathrm{wk}$, samples with no CPE were re-inoculated into a new culture of EPC cells. After 2 wk, the sample was considered negative if no CPE was observed. Cell cultures with positive CPE were stored at $-80^{\circ} \mathrm{C}$.

From fish infected with each of the 6 Ranavirus isolates, 3 samples were sent to $H$. Tapiovaara and $R$. Holopainen (Evira, Finland) for PCR amplification and sequencing. Material was taken from both homogenised fish and first passage in EPC cells. The major capsid protein was sequenced in 3 parts, using the primers recommended by the OIE (2006) and described by Hyatt et al. (2000). Sequencing was done to confirm the identity of the viral isolates in the treatments and rule out the possibility of cross-contamination between the aquaria.
Immunohistochemistry (IHC) and histopathology. For all immunological staining, a polyclonal rabbit anti-ECV antibody (provided by G. Bovo, Instituto Zooprofilattico Sperimentale delle Venezie, Italy) was used as the primary antibody. This antibody is expected to cross-react with all the Ranavirus isolates used in this study, and is specific to ranaviruses (G. Bovo pers. comm.).

After fixation in $10 \%$ phosphate buffered formalin for a minimum of $24 \mathrm{~h}$, whole individuals were embedded in paraffin wax. Selected individuals of both the infected and negative control groups were sectioned and stained with haematoxylin and eosin (H\&E) by conventional methods. A total of 22 samples from fish infected with each of the viral isolates was prepared for immunohistochemistry using the protocol described by Evensen \& Lorenzen (1996) as briefly described below.

The tissue sections were dewaxed and hydrated through gradients of alcohol, and incubated in Tris buffered saline (TBS, pH 7.2) with $5 \%$ bovine serum albumin (BSA) for $20 \mathrm{~min}$ at room temperature. The slides were then incubated with polyclonal rabbit antiECV antibody diluted to 1:1500 in TBS buffer with $2.5 \%$ BSA for $1 \mathrm{~h}$ at room temperature. After washing with TBS, a biotinylated swine anti-rabbit IgG antibody (Dako) diluted to 1:300 in TBS buffer with 2.5\% BSA was added, and the slides incubated for $1 \mathrm{~h}$ at room temperature. The slides were then rinsed with TBS, incubated with Streptavidin-AP (Dako) diluted to 1:200 in TBS buffer with $2.5 \%$ BSA for 40 min at room temperature, washed with TBS, and a chromogen substrate was added (Fast Red, Kem-En-Tec) for $20 \mathrm{~min}$. 
Finally, the slides were counterstained with haematoxylin, mounted with Aquamount (Merck), and examined under a light microscope.

Immunofluorescence. Samples from either the homogenised fish or first passage in EPC cells from pike infected with EHNV, ECV, ESV, PPIV, FV3, NZeelV and VHS were inoculated onto EPC cells in 96 well plates and incubated for $24 \mathrm{~h}$ at $20^{\circ} \mathrm{C}$. Homogenised fish from the negative control tanks were used as control. After fixation with $80 \%$ acetone, $20 \mu \mathrm{l}$ of the rabbit anti-ECV antibody at 1:800 dilution in phosphate buffered saline (PBS, pH 7.5, without $\mathrm{Ca}^{2+}$ and $\mathrm{Mg}^{2+}$ ) was added to each well, and the plate was incubated at $37^{\circ} \mathrm{C}$ for $30 \mathrm{~min}$. The plate was rinsed with $0.05 \%$ PBS-Tween $3 \times$, added with $30 \mu \mathrm{l}$ secondary antibody (TRITC conjugated swine antirabbit $\operatorname{IgG}$ ) at $1: 100$ dilution, incubated at $37^{\circ} \mathrm{C}$ for $30 \mathrm{~min}$, washed with $0.05 \%$ PBS-Tween $3 \times$, and air dried. The samples were then examined using a fluorescence microscope.

Statistical analysis. Statistical analysis was performed using Statistical Analysis System version 9.1 (SAS Institute) using a 5\% significance level.

Differences in cumulative mortalities between challenged and control fish in the duplicate aquaria were tested using ANOVA (PROC MIXED in SAS). The proportion of dead fish to total fish in the tank was the continuous outcome. The temperature in the aquarium (12 and $22^{\circ} \mathrm{C}$ ), the viral isolate (EHNV, ESV, ECV, PPIV, NZeelV and FV3), and the interaction between temperature and viral isolate were investigated as fixed effects, in order to take into account the duplicate tanks for each temperature*virus combination. The variation between the 2 aquaria within each temperature and viral isolate constitutes the residual variation.

Statistical analysis of the factors influencing the outcome of virus re-isolation was performed using logistic regression with repeated measurements, the positive or negative CPE results being used as the binomial outcome (GLIMMIX MACRO in SAS). The following factors were investigated as fixed effects: temperature in the aquarium $\left(12\right.$ and $\left.22^{\circ} \mathrm{C}\right)$, viral isolate (EHNV, ESV, ECV, PPIV, NZeelV and FV3), number of days after infection, and number of fish in the sample. Due to the low sample size, the number of days after infection was divided into 4 wk plus a group with samples from fish euthanized at the end of the trial. The number of fish in the sample was divided into 6 categories: $1,2,3,4-5,6-10$ and $>10$ fish. Differences between duplicate aquaria with the same temperature and isolate were estimated by including aquarium nested within temperature and isolate as a random effect. The autocorrelation between repeated samples within the same aquarium was taken into account by using a firstorder autoregressive correlation structure.

\section{RESULTS}

At $22^{\circ} \mathrm{C}$, mortality started at Days 2 to 3 for all isolates, and ceased at Days 4 to 5 (EHNV and FV3), Day 8 (ECV) and Days 10 to 12 at the latest (ESV, PPIV, NZeelV and VHS) (Fig. 1). At $12^{\circ} \mathrm{C}$, the mortality curves of the different isolates were more variable. Mortality started at Day 2 for FV3 and had ceased by Day 7. For EHNV and NZeelV, mortality was observed from Day 4 to Days 13 to 14 . Mortality in ESV, ECV and PPIV did not start until Day 7, but continued throughout the study period. In the negative control group, continuous mortality was seen throughout the study, the cumulative mortality being higher and the mortality curve more abrupt in control fish kept at $22^{\circ} \mathrm{C}$ compared with those at $12^{\circ} \mathrm{C}$. The VHS-infected fry started dying at Day 2, reaching $100 \%$ mortality on Day 8 at $12^{\circ} \mathrm{C}$, and $96 \%$ mortality on Day 10 at $22^{\circ} \mathrm{C}$, indicating that VHSV was a satisfactory positive control of the infection model. A statistically significant difference between the infected and the control groups was detected for the ranaviruses EHNV, ESV, PPIV and $\mathrm{NZeelV}$ at $12^{\circ} \mathrm{C}$, whereas no statistical significance was found between infected and control groups at $22^{\circ} \mathrm{C}$ (Table 2). In both infected and non-infected fish, cannibalism was observed. Fry with the tail of a sibling protruding from the mouth were regularly observed, but only one cannibal was noted in most aquaria. The cannibal could be up to $3 \times$ larger than its siblings at the end of the challenge (Fig. 2). If a cannibalistic fish died, one of the other fry in the tank would normally take over the cannibalistic role. The fish that were cannibalised were not included in the calculation of mortalities.

\section{Virus re-isolation}

For all the isolates, there was a high degree of positive virus re-isolation in at least one of the temperature treatments (Table 3). The observed CPE was consistent with that for other ranaviruses: initial condensation and rounding of cells, development into plaques surrounded by rounded cells in the cell monolayers, and eventual detachment of all cells. No CPE was seen in any of the samples from the negative control fish. All the positive samples showed CPE in all 3 dilutions, giving a viral titre of at least $10^{4} \mathrm{TCID}_{50}$ per sample.

The number of fish in the sample and the viral isolate had a significant influence on $\mathrm{CPE}$, but there was no effect due to temperature in the aquarium or number of days after infection. The higher the number of fish in the sample, the higher was the likelihood of a positive $\mathrm{CPE}$, although this effect was not seen with $>10$ fish. The likelihood of a positive CPE was higher for sam- 

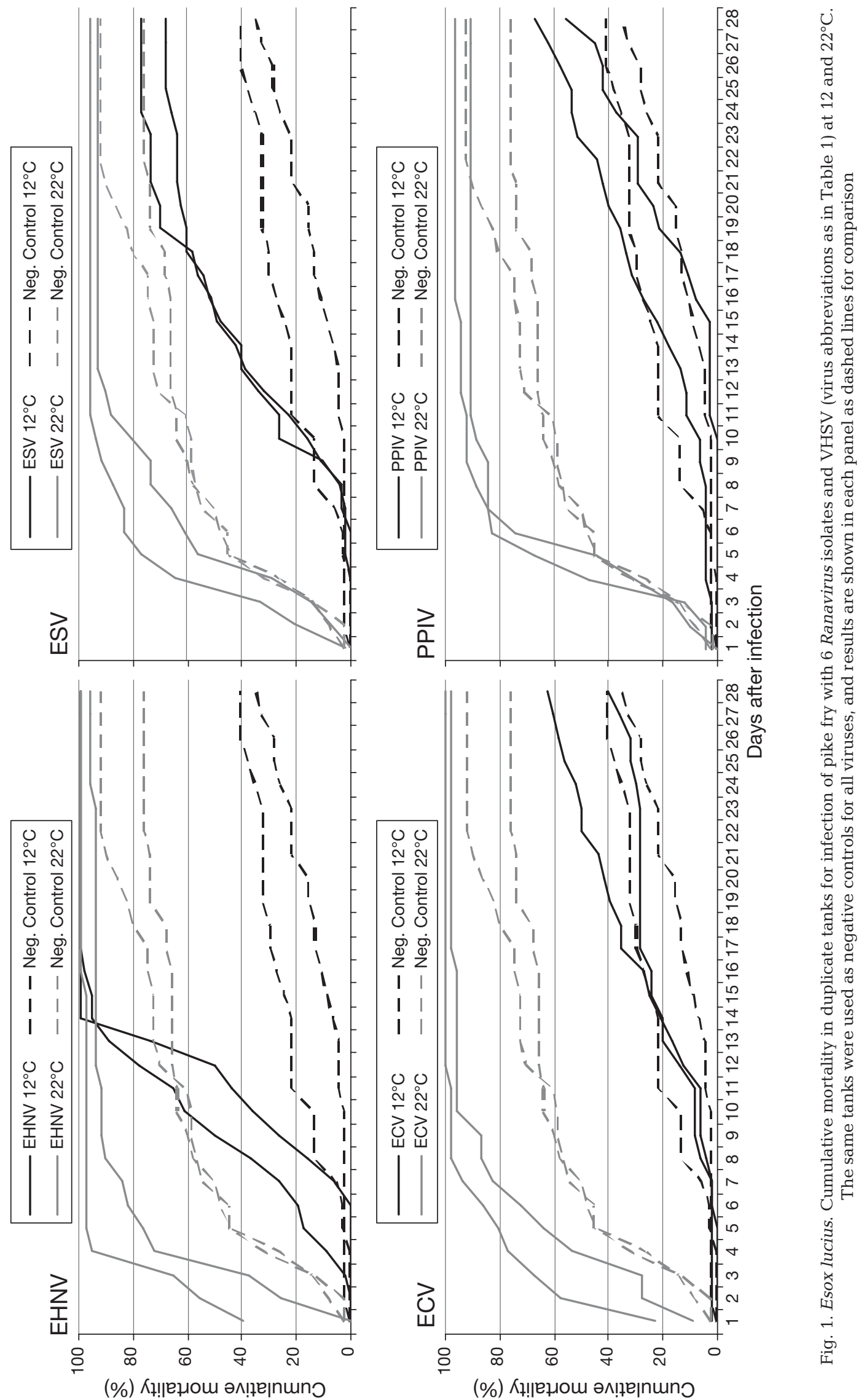


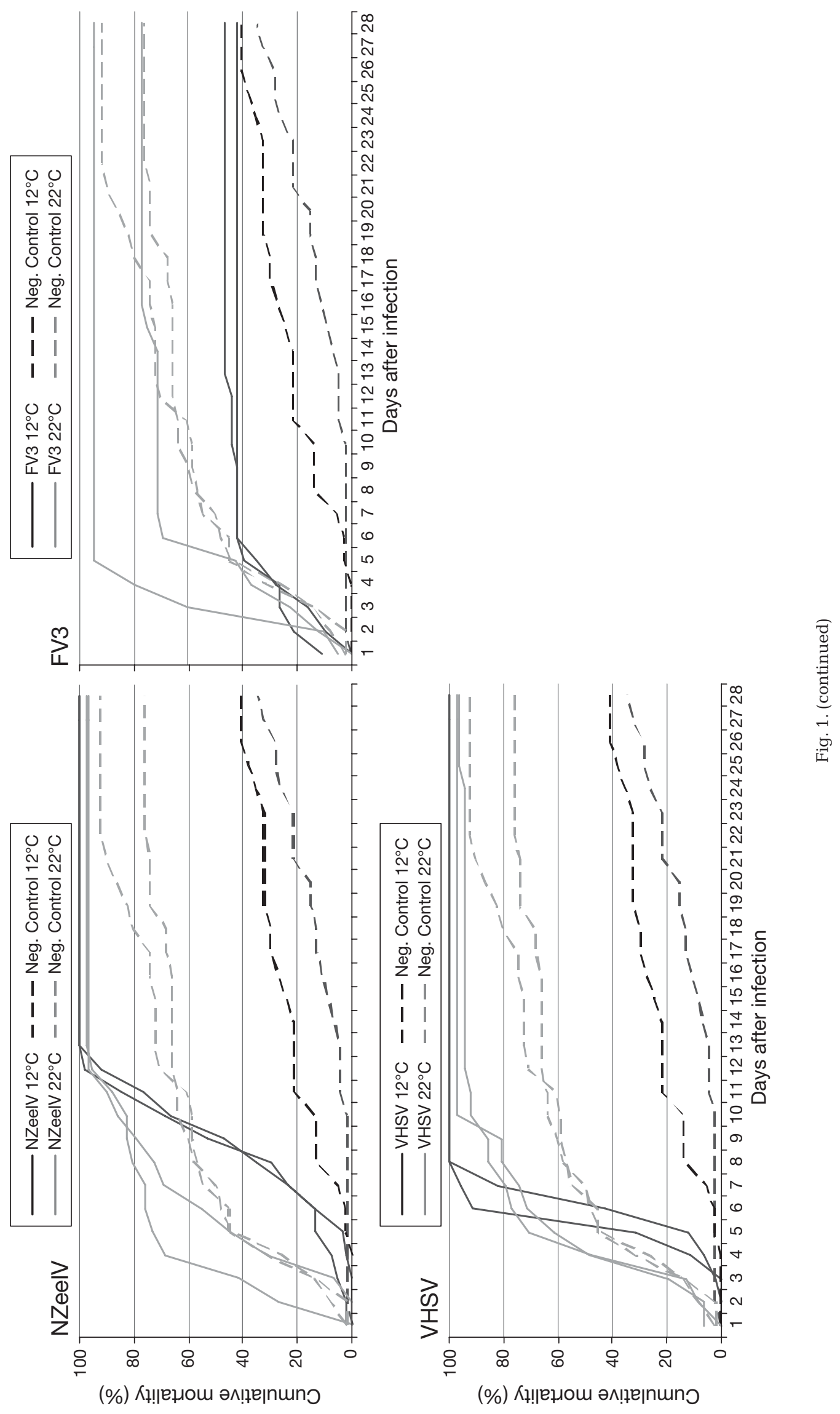


Table 2. Pathogenicity of 6 Ranavirus isolates and VHSV for Esox lucius. p-values are based on ANOVA of mortality between Ranavirus isolates and negative controls, in which the expected proportions of mortality were comparable to those calculated from the duplicate tanks together and shown here. Bold values indicate $\mathrm{p}<0.05$. n.d.: not determined (since VHSV was used as a positive control). Virus abbreviations as in Table 1

\begin{tabular}{|lcccc|}
\hline $\begin{array}{l}\text { Virus } \\
\text { isolate }\end{array}$ & $\begin{array}{c}\text { No. of ind. } \\
\text { in tank }\end{array}$ & $\begin{array}{c}\text { Total } \\
\text { dead ind. }\end{array}$ & $\begin{array}{c}\text { Mortality } \\
(\%)\end{array}$ & $\mathrm{p}$ \\
\hline $\mathbf{1 2}{ }^{\circ} \mathbf{C}$ & & & & \\
EHNV & 96 & 96 & 100 & $<\mathbf{0 . 0 0 1}$ \\
ESV & 107 & 78 & 73 & $<\mathbf{0 . 0 0 1}$ \\
ECV & 98 & 50 & 51 & 0.076 \\
PPIV & 83 & 51 & 61 & $\mathbf{0 . 0 0 5}$ \\
NZeelV & 102 & 102 & 100 & $<\mathbf{0 . 0 0 1}$ \\
FV3 & 81 & 36 & 44 & 0.364 \\
VHSV & 94 & 94 & 100 & n.d. \\
Neg. control & 83 & 31 & 37 & n.d. \\
$\mathbf{2 2}{ }^{\circ} \mathbf{C}$ & & & & \\
EHNV & 94 & 92 & 98 & 0.069 \\
ESV & 185 & 180 & 97 & 0.172 \\
ECV & 99 & 98 & 98 & 0.055 \\
PPIV & 101 & 94 & 93 & 0.223 \\
NZeelV & 70 & 68 & 97 & 0.088 \\
FV3 & 69 & 57 & 83 & 0.761 \\
VHSV & 79 & 76 & 96 & n.d. \\
Neg. control & 101 & 85 & 84 & n.d. \\
\hline
\end{tabular}

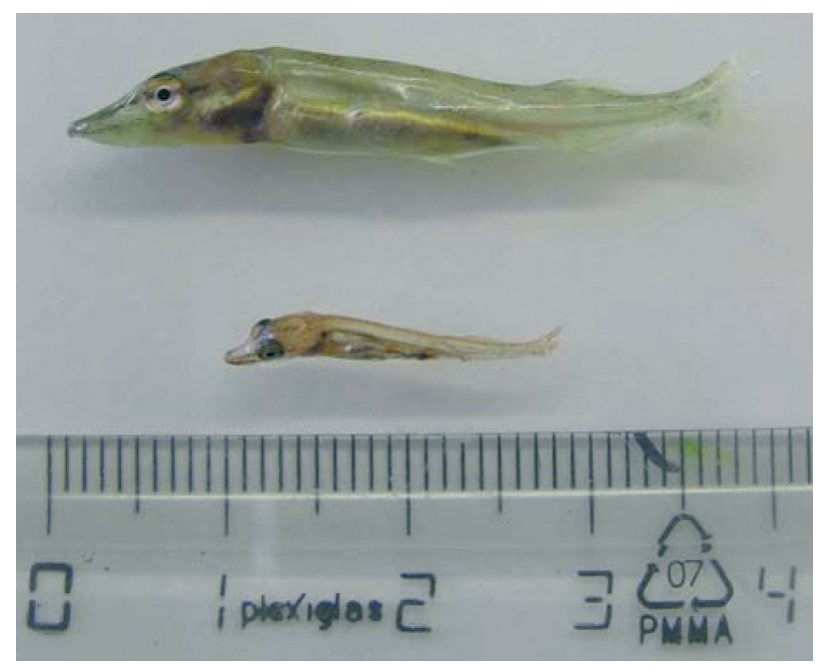

Fig. 2. Esox lucius. Fry of the same age $(\sim 40$ d) and from the same tank

ples from fish infected with PPIV, EHNV and ESV than for those infected with ECV, NZeelV and FV3 (Table 4).

The sequencing results confirmed that all the 6 Ranavirus isolates obtained from the infected fish were identical to the viral isolate with which the fish had been infected (results not shown).
Table 3. Re-isolation of ranaviruses in epithelioma papulosum cyprinid (EPC) cells at $20^{\circ} \mathrm{C}$. CPE: cytopathic effect. Virus abbreviations as in Table 1

\begin{tabular}{|lccc|}
\hline Virus isolate & $\begin{array}{c}\text { No. of } \\
\text { samples }\end{array}$ & $\begin{array}{c}\text { Positive } \\
\text { CPE }\end{array}$ & $\begin{array}{c}\text { Positive } \\
\text { CPE (\%) }\end{array}$ \\
\hline $\mathbf{1 2}{ }^{\circ} \mathbf{C}$ & & & \\
EHNV & 22 & 21 & 95 \\
ESV & 28 & 15 & 54 \\
ECV & 27 & 10 & 37 \\
PPIV & 31 & 26 & 84 \\
NZeelV & 17 & 14 & 82 \\
FV3 & 15 & 9 & 60 \\
VHSV & 11 & 10 & 91 \\
Neg. control & 25 & 0 & 0 \\
$\mathbf{2 2}{ }^{\circ} \mathbf{C}$ & & & \\
EHNV & 17 & 14 & 82 \\
ESV & 33 & 31 & 94 \\
ECV & 19 & 13 & 68 \\
PPIV & 20 & 20 & 100 \\
NZeelV & 22 & 0 & 0 \\
FV3 & 15 & 9 & 60 \\
VHSV & 20 & 0 & 0 \\
Neg. control & 31 & 0 & 0 \\
\hline
\end{tabular}

\section{Immunohistochemistry and histopathology}

Of the 22 samples tested by IHC using anti-ECV antibody, 15 were positive, with at least 1 positive sample for each viral isolate. The most distinct reactions were seen in the EHNV-infected samples (Fig. 3). The virus was most often detected in the liver, heart, kidney, spleen and gills, but positive foci were also seen in the intestinal wall, muscle or pancreas of some samples. Infected cells showed hypertrophy, vacuolization and pyknotic nuclei or karyorrhexis (Fig. 3A,B). In all H\&E stained samples, melanocytes were present in large numbers, especially in the gills and kidneys. The renal interstitium was destroyed, with extensive cell necrosis and haemorrhaging. Cells showing hypertrophy and haemorrhaging were also seen in the sinusoids. In the gills, the most common lesions were hydropic changes and karyorrhexis in the epithelial cells. Samples from negative control fish showed none of the above mentioned lesions, and no signs of ecto- or endoparasites were present in any of the histological samples.

\section{Immunofluorescence}

Cell cultures inoculated with homogenised pike infected with EHNV, ECV, ESV, PPIV, NZeelV and FV3 all showed positive immunofluorescence when stained with polyclonal rabbit anti-ECV antiserum as the primary antibody. No positive staining was seen in cells inoculated with VHS-infected fish or the negative 
Table 4. Factors associated with positive re-isolation of ranaviruses. Levels within the same effect with the same superscript letters are not significantly different at $p<0.05$. SE: standard error; CI: confidence interval. Virus abbreviations as in Table 1

\begin{tabular}{|lcccccc|}
\hline Variable & Level & Estimate & SE & $\begin{array}{c}\text { Odds ratio } \\
\text { (OR) }\end{array}$ & $\begin{array}{c}\text { CI of the } \\
\text { OR }\end{array}$ & $p$ \\
\hline Intercept & & -0.747 & 0.873 & & & \\
Pool & & & & & & $<0.001$ \\
& 1 ind. & $0.00^{\mathrm{c}}$ & 0.000 & 1.00 & n.d. & \\
& 2 ind. & $0.82^{\mathrm{b}}$ & 0.414 & 2.27 & $1.01-5.11$ & \\
& 3 ind. & $1.26^{\mathrm{a}, \mathrm{b}}$ & 0.474 & 3.52 & $1.39-8.91$ & \\
& $4-5$ ind. & $2.04^{\mathrm{a}}$ & 0.504 & 7.71 & $2.87-20.68$ & \\
& 6-10 ind. & $2.22^{\mathrm{a}}$ & 0.636 & 9.20 & $2.65-31.96$ & \\
& $>10$ ind. & $1.68^{\mathrm{a}, \mathrm{b}}$ & 0.559 & 5.37 & $1.79-16.06$ & \\
& & & & & & 0.043 \\
Isolate & & & & & \\
& EHNV & $2.05^{\mathrm{a}, \mathrm{b}}$ & 12.71 & 7.76 & $0.64-93.68$ & \\
& ESV & $1.03^{\mathrm{a}, \mathrm{b}, \mathrm{c}}$ & 11.77 & 2.80 & $0.28-28.08$ & \\
& ECV & $-0.34^{\mathrm{b}, \mathrm{c}}$ & 11.73 & 0.71 & $0.07-7.10$ & \\
PPIV & $3.09^{\mathrm{a}}$ & 13.54 & 21.97 & $1.55-312.44$ & \\
& NZeelV & $-1.45^{\mathrm{c}}$ & 12.27 & 0.23 & $0.02-2.60$ & \\
& FV3 & $0.00^{\mathrm{b}, \mathrm{c}}$ & 0.00 & 1.00 & n.d. & \\
& & & & & &
\end{tabular}

control fish. The strongest reactions were seen in EHNV-, ECV- and ESV-infected samples, where the rounded cells lining the plaques in the cell monolayer showed fluorescence (Fig. 4). The PPIV- and FV3-infected cell monolayers showed only a weak positive reaction in cells scattered throughout the field of vision. In the cell monolayers inoculated with homogenised NZeelV-infected fish, positive cells were characterised by elongation and fluorescence of the cell membranes.

\section{DISCUSSION}

The present study shows that pike fry are susceptible to 4 different Ranavirus isolates at $12^{\circ} \mathrm{C}$. Due to the high background mortality at $22^{\circ} \mathrm{C}$, it was

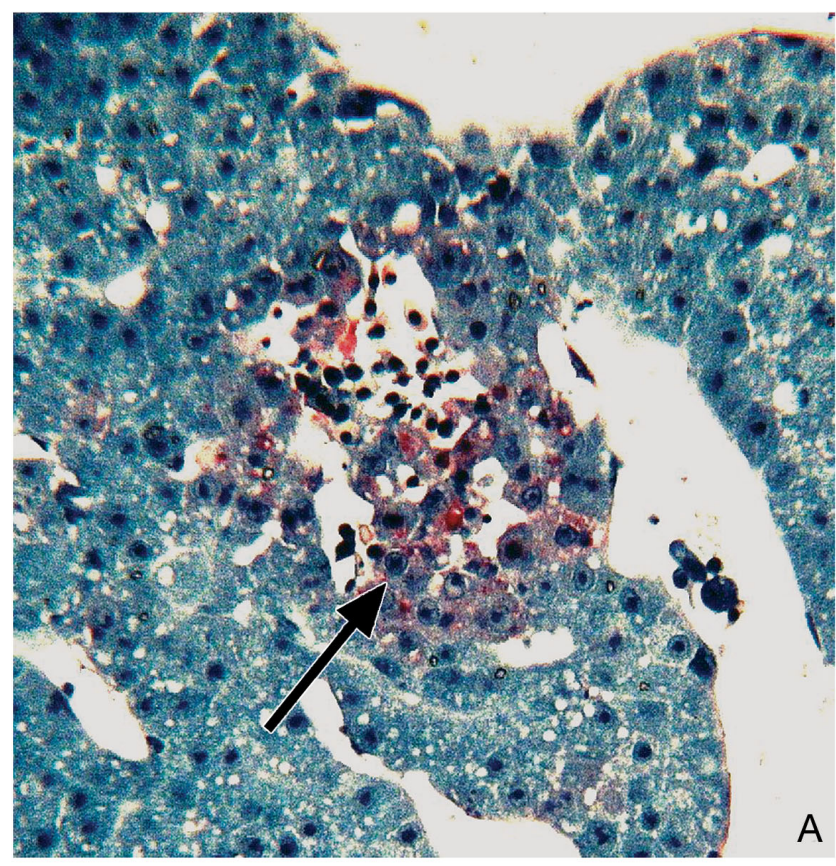

Fig. 3. Esox lucius. Photomicrographs of pike fry organ samples from Day 14 after infection with epizootic haematopoietic necrosis virus (EHNV). The tissue is stained with anti-ECV (European catfish virus), showing positive reaction as red foci (Fast-red). (A) Liver (10×) showing degenerative and necrotic changes in virus-positive foci (arrow). (B) Gill $(40 \times)$ showing hydropic cells with karyorrhexis and positive staining for Ranavirus in cytoplasm (arrow). (C) The same section of liver as in (A) but stained with anti-VHSV (viral haemorrhagic septicaemia virus) is shown for comparison. No positive reaction is seen in (C)

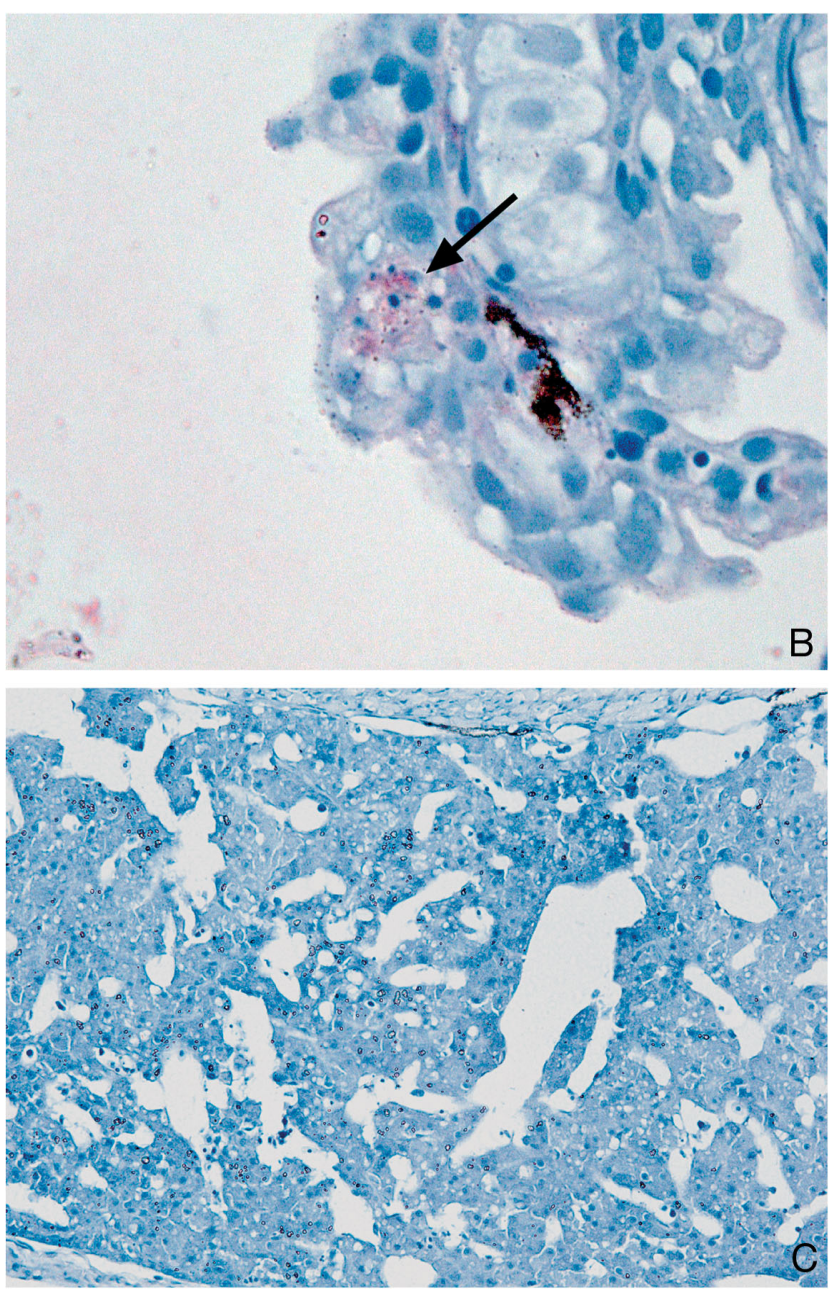




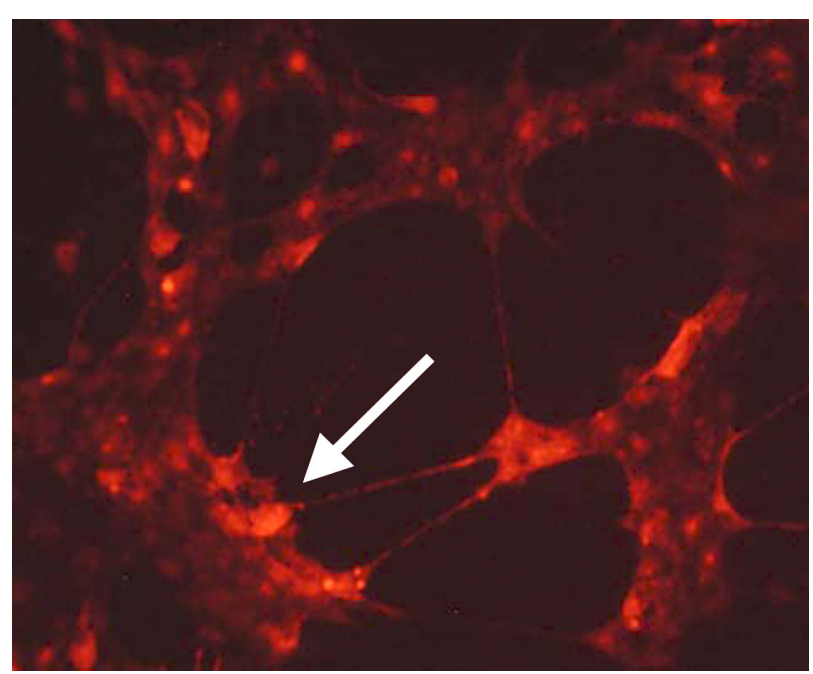

Fig. 4. Photomicrograph of fluorescent epithelioma papulosum cyprinid (EPC) cells (40×) inoculated with homogenised organ material from pike fry infected with epizootic haematopoietic necrosis virus (EHNV). The cells were fixed after $24 \mathrm{~h}$ and stained with anti-ECV (European catfish virus). Virus-positive foci are seen as light-red fluorescent areas (arrow)

not possible to draw any conclusions about the pathogenicity of ranaviruses to pike fry at this temperature. However, the high degree of positive virus re-isolation indicates that the viruses can indeed infect the fish.

Although it is not known how closely related PPIV and NZeelV are to the other groups within the genus, this study shows that the infective properties are very similar across the panel of viral isolates. The mortality curves and the pathological changes were comparable, and the antibody against ECV could be used for all viral isolates in both immunohistochemistry and immunofluorescence, although the ECV group (ECV and ESV) and the closely related EHNV yielded the strongest reactions in IHC using anti-ECV antibody. ECV and FV3 did not cause mortalities that were significantly different from those in the control group. Nevertheless, it was possible to re-isolate the virus from the fish in more than half of the samples. Formalin-fixed samples were positive based on immunohistochemistry, and the virus could be identified by immunofluorescence of infected cell cultures. This indicates that pike can be carriers of ECV and FV3, although the virus may not be pathogenic to the fish.

Mortality rate among the fry was high, both in the exposed and the control groups. The background mortality could have been due to the pike being unaccustomed to the culture conditions, and to baseline die-offs of non-viable fry. The rapid increase in temperature from 12 to $22^{\circ} \mathrm{C}$ may have also contributed to the elevated mortality observed at $22^{\circ} \mathrm{C}$. Increasing cannibalism was also observed during the study period. Cannibalism is common in pike fry and can be greatly reduced if the food supply is adequate and cannibalistic fish are removed from the system (Diana 1996). The fish in this study were fed with Artemia for practical reasons, although it is not known whether this is suitable feed for pike fry. In the present study, cannibalistic fish were not removed, but the mortalities registered were based on dead fish removed and fish surviving until the end of the trial. It is not known whether the fish that were eaten by cannibals were infected or not, and what influence this would have had on the final mortality.

Because pike are very difficult to work with under experimental conditions, the present study was performed only with pike fry. Therefore, it is not known whether ranaviruses are also pathogenic to older fish. Meier (1985) showed that the susceptibility of pike to VHSV decreased with the age of the fish. After 2 yr of age, infection did not result in disease, but fish could still carry the virus. In a study similar to the current one, Dorson et al. (1987) examined the susceptibility of pike fry to different rhabdoviruses and IPN. In that study, 2 age groups of pike were used for challenge with IPN: one group of $10 \mathrm{~d}$ old and another of $9 \mathrm{wk}$ old fry. Dorson et al. (1987) observed up to $70 \%$ mortality in the younger group, whereas the older group demonstrated complete resistance to infection. Further studies are needed to determine the susceptibility of older pike to ranaviruses.

Virus re-isolation percentages were high from all viral treatments, except for NZeelV at $22^{\circ} \mathrm{C}$. Since the re-isolation was performed on fish that had died during challenge, a re-isolation close to $100 \%$ may have been expected. However, considering the high mortality in the control group, it is likely that some of the mortalities in the challenged groups were due to the same causes that killed the fish in the control groups. Since only one infected fish is needed for a positive CPE, the likelihood of getting positive CPE results increases with the number of fish in the sample, as observed in the present study. When there were $>10$ fish, this effect disappeared, probably due to the dilution effect of many virus-negative fish in the same sample. In the analysis, we did not detect an effect of the number of days after infection on the possibility of getting a positive CPE-result. This is probably due to the very low sample sizes in all but the first 2 wk of the study (mortality was negligible thereafter), thus reducing the number of samples available for viral re-isolation. Surprisingly, there was no significant difference in the number of virus-positive samples between fish from cold and warm water, although the cumulative mortality in fish infected with ESV, ECV, PPIV and FV3 in cold water was lower than that in warm water and the onset of mortality occurred later. The earlier onset of 
mortality in warmer water is consistent with the generally faster uptake and replication of viruses at higher temperatures. Furthermore, it is possible that the fish were stressed by the higher temperature, leading to immunosuppression and higher susceptibility to viral infection. Whittington \& Reddacliff (1995) showed that $12^{\circ} \mathrm{C}$ is the lower limit for onset of mortality caused by infection with EHNV in redfin perch and rainbow trout, and that the incubation time decreased with increasing temperature. For NZeelV and VHSV, it is remarkable that pathogenicity and viral isolation are higher, although not significantly so, at lower temperatures, and that mortality curves for these viral isolates are very similar. VHSV is known to be a cold-water virus that does not replicate well above $20^{\circ} \mathrm{C}$ (de Kinkelin et al. 1980), and the same may be true for NZeelV.

The pike fry used in this study were raised in water temperatures of $\sim 10$ to $15^{\circ} \mathrm{C}$ before the trial, and the higher temperature may have been a stress factor, since the change from cold to warm water was relatively quick. The optimum growth temperature for pike is normally $\sim 21^{\circ} \mathrm{C}$ (Casselman 1996). Since this temperature is also the most suitable for infection with ranaviruses, it is likely that high mortality associated with a natural outbreak of ranaviruses would be seen in pike fry, if the outbreak occurs in summer when water temperatures in Europe can be relatively high.

The fry were too small to reveal any gross pathological findings, but the histopathological finding of poorly defined sinusoids in kidneys suggests mortality due to renal insufficiency. The lesions seen in the pike fry were very similar to those described for infection with EHNV in rainbow trout and redfin perch (Reddacliff \& Whittington 1996), with lesions in multiple organs, especially affecting haematopoietic cells and the endothelium. The protocol used for IHC and immunofluorescence worked well for all the viruses in the panel. IHC proved to be a valuable method for identifying which organs and cells contained viral antigens. The antibody used (anti-ECV) gave the best results with the isolates that were more closely related to ECV, i.e. EHNV and ESV, although all the ranaviruses could be identified using this antibody. Due to the above mentioned cross-reactivity of anti-ECV with the other ranaviruses included in the present study, neither IHC nor IFAT (immunofluorescent antibody technique) can be used to differentiate between the ranaviruses.

The finding that pike fry are susceptible to ranaviruses is very important for an understanding of the epidemiology of the diseases. A common practice in many countries is to rear and release pike fry in freshwater lakes for sports fishing or regulatory purposes, thereby creating easy pathways for the spread of Ranavirus-infected fish through the ecosystem. It is still necessary to determine whether other fish species can contract the disease by feeding on pike fry or by cohabiting in the same water system, since knowledge about the shedding and the natural pathways for infection of ranaviruses is scarce.

This is the first report of ESV, PPIV and NzeelV pathogenicity to a species other than the original host, and the first study to show that fish can be subclinically infected with an amphibian virus, FV3.

The finding of a new fish vector species for these Ranavirus isolates (including EHNV and ECV) implies that the viruses may also be pathogenic to other fish species and is important to consider in investigating the possibility of the introduction and spread of ranaviruses in Europe.

Acknowledgements. The study was funded by the EU project 'Risk assessment of new and emerging systemic iridoviral diseases for European fish and aquatic ecosystems' under the 6th framework programme. We thank G. Bovo (IZS-VE, Padova, Italy) for providing the anti-ECV antibody and the protocol for $\mathrm{IHC}_{\text {; }}$ and H. Tapiovaara and R. Holopainen (Evira, Helsinki, Finland) for sequencing.

\section{LITERATURE CITED}

Ahne W (1978) Isolation and characterization of infectious pancreatic necrosis virus from pike (Esox lucius). Arch Virol 58:65-69

Ahne W, Schlotfeldt HJ, Thomsen I (1989) Fish viruses: isolation of an icosahedral cytoplasmic deoxyribovirus from sheatfish (Silurus glanis). J Vet Med B 36:333-336

Anonymous (2001) Laying down the sampling plans and diagnostic methods for the detection and confirmation of certain fish diseases and repealing Decision 92/532/EEC. Commission Decision of 22 February 2001, 2001/183/EC. European Commision, Brussels

Bovo G, Giacometti P, Montesi, F, Cappellozza E \& Ormelli S (1999) Isolation of an iridovirus-like agent from New Zealand eel. 9th Int Conf European Assoc Fish Pathologists, Rhodes, Greece, 19-24 Sep, p 153 (Abstract)

Casselman JM (1996) Age, growth and environmental requirements of pike. In: Craig JF (ed) Pike: biology and exploitation. Chapman \& Hall, London, p 69-101

Chinchar VG, Essbauer S, He JG, Hyatt AD, Miyazaki T, Seligy V, Williams T (2005) Family Iridoviridae. In: Fauquet CM, Mayo MA, Maruloff J, Desselberger U, Ball A (eds) Virus taxonomy. 8th report of the International Committee on Taxonomy of Viruses. Elsevier, San Diego, CA, p 145-162

Crossman EJ (1996) Taxonomy and distribution. In: Craig JF (ed) Pike: biology and exploitation. Chapman \& Hall, London, $\mathrm{p}$ 1-11

de Kinkelin P, Bearzotti-Le Berre M, Bernard J (1980) Viral haemorrhagic septicaemia of rainbow trout: selection of a thermoresistant virus variant and comparison of polypeptide synthesis with the wild-type virus strain. J Virol 36: 652-658

Diana JS (1996) Energetics. In: Craig JF (ed) Pike: biology and exploitation. Chapman \& Hall, London, p 103-124 
Dick TA, Choudhury A (1996) Parasites, diseases and disorders. In: Craig JF (ed) Pike: biology and exploitation. Chapman \& Hall, London, p 157-184

Dorson M, de Kinkelin P, Torchy C, Monge D (1987) Sensibilité du brochet (Esox lucius) à different virus de salmonidés (NPI, SHV, NHI) et au rhabdovirus de la perche. Bull Fr Pêche Piscic 307:91-101

Evensen Ø, Lorenzen E (1996) An immunohistochemical study of Flexibacter psychrophilus infection in experimentally and naturally infected rainbow trout (Oncorhynchus mykiss) fry. Dis Aquat Org 25:53-61

Granoff A, Came PE, Breeze DC (1966) Viruses and renal carcinoma of Rana pipiens. I. Isolation and properties of virus from normal and tumor tissue. Virology 29:133-148

Hedrick RP, McDowell TS (1995) Properties of iridoviruses from ornamental fish. Vet Res 26:423-427

Hyatt AD, Gould AR, Zupanovic Z, Cunningham AA and others (2000) Comparative studies of piscine and amphibian iridoviruses. Arch Virol 145:301-331

Langdon JS (1989) Experimental transmission and pathogenicity of epizootic haematopoietic necrosis virus (EHNV) in redfin perch, Perca fluviatilis L., and 11 other teleosts. J Fish Dis 12:295-310

Langdon JS, Humphrey JD, Williams LM, Hyatt AD, Westbury HA (1986) First virus isolation from Australian fish: an iridovirus-like pathogen from redfin perch Perca fluviatilis. J Fish Dis 9:263-268

Langdon JS, Humphrey JD, Williams LM (1988) Outbreaks of an EHNV-like iridovirus in cultured rainbow trout, Salmo giardneri Richardson, in Australia. J Fish Dis 11:93-96

Lorenzen E (1993) The importance of the brand of the beef extract in relation to the growth of Flexibacter psychrophilus in Anacker \& Ordals medium. Bull Eur Assoc Fish Pathol 13:64-65

Lorenzen N, Olesen NJ, Jørgensen PEV (1993) Antibody response to VHS virus proteins in rainbow trout. Fish Shellfish Immunol 3:461-473

Mann RHK (1996) Fisheries and economics. In: Craig JF (ed)
Pike: biology and exploitation. Chapman \& Hall, London, p 219-241

Mao JH, Green DE, Fellers G, Chinchar VG (1999) Molecular characterization of iridoviruses isolated from sympatric amphibians and fish. Virus Res 63:45-52

Meier W (1985) Viral haemorrhagic septicaemia: susceptibility of pike (Esox lucius L.) and its epizootiological role. J Appl Ichthyol 1:171-177

Meier W, Jørgensen PEV (1980) Isolation of VHS virus from pike fry (Esox lucius) with haemorrhagic symptoms. In: Ahne W (ed) Fish diseases. Springer-Verlag, Berlin, p 8-17

Moody NJG, Owens L (1994) Experimental demonstration of the pathogenicity of a frog virus, Bohle iridovirus, for a fish species, barramundi Lates calcarifer. Dis Aquat Org 18: 95-102

Nakajima K, Maeno Y (1998) Pathogenicity of red sea bream iridovirus and other iridoviruses to red sea bream. Fish Pathol 33:143-144

OIE (2006) Epizootic haematopoietic necrosis. In: Manual of diagnostic tests for aquatic animals, 11th edn, Chap 2.1.1. World Organisation for Animal Health, Paris, p 82-103

> Pozet F, Morand M, Moussa A, Torhy C, de Kinkelin P (1992) Isolation and preliminary characterization of a pathogenic icosahedral deoxyribovirus from the catfish Ictalurus melas. Dis Aquat Org 14:35-42

> Reddacliff LA, Whittington RJ (1996) Pathology of epizootic haematopoietic necrosis virus (EHNV) infection in rainbow trout (Oncorhynchus mykiss Walbaum) and redfin perch (Perca fluviatilis L). J Comp Pathol 115:103-115

Tapiovaara H, Olesen NJ, Lindén J, Rimaila-Pärnänen E, von Bonsdorff $\mathrm{CH}$ (1998) Isolation of an iridovirus from pikeperch Stizostedion lucioperca. Dis Aquat Org 32:185-193

> Whittington RJ, Reddacliff GL (1995) Influence of environmental temperature in experimental infection of redfin perch (Perca fluviatilis) and rainbow trout (Onchorhynchus mykiss) with epizootic haematopoietic necrosis virus, an Australian iridovirus. Aust Vet J 72:421-424

Submitted: July 4, 2008; Accepted: December 8, 2008

Proofs received from author(s): February 18, 2009
Editorial responsibility: Mark Crane,

Geelong, Victoria, Australia 